\title{
INTEGRATED STRATEGY TO ENHANCE BIOGAS PRODUCTION FROM MANGO PEEL WASTE
}

\author{
SURYAWANSHI P.C. ${ }^{1, *}$ \\ SATYAM A. ${ }^{1}$ \\ CHAUDHARI A.B. ${ }^{2}$
}

\author{
${ }^{1}$ Jain $R \&$ D Laboratory, Agri Park, Jain Hills \\ Jain Irrigation Systems Ltd, Jalgaon 425001, India \\ ${ }^{2}$ Department of Microbiology, School of Life Sciences \\ North Maharashtra University, Jalgaon 425001 (India)
}

*to whom all correspondence should be addressed: Accepted: $21 / 05 / 13$ e-mail: biogaslab@jains.com

\begin{abstract}
The present study has successfully explored the use of pomegranate seed de-oiled cake as a major additive and micronutrients solution as a minor additive to enhance production of biogas and enrich its methane content, using mango peel as the initial substrate. While micronutrients solution has activated enzymes to carry out anaerobic digestion for optimal production of biogas and methane, pomegranate seed de-oiled cake has (a) provided buffering capacity for stabilized pH/alkalinity: acidity ratio, (b) reduced $\mathrm{C}: \mathrm{N}$ ratio of the substrates to facilitate anaerobic digestion. Cumulatively effecting enhanced biogas generation $\left(0.82 \mathrm{~m}^{3} \mathrm{~kg}^{-1} \mathrm{VS}\right.$ fed) and its rich methane content $\left(0.64 \mathrm{~m}^{3} \mathrm{~kg}^{-1}\right.$ VS fed).
\end{abstract}

KEYWORDS: Mango peel waste, anaerobic digestion, de-oiled cake of pomegranate seeds, micronutrients, enhanced biogas/methane production.

\section{INTRODUCTION}

Anaerobic digestion of fruit waste represented a feasible technology to reduce the environmental burden, which otherwise could cause putrefaction and health hazards, if the waste remained unattended and at the same time provides biogas with 60-65\% methane content for energy needs. (Gomez et al., 2007; Kirtane et al., 2009). In addition, the digested effluent slurry (digestate) is useful as an organic manure to amend soil fertility (Chaudhari and Kothari, 2009).

However, computation based upon total organic carbon and especially \% volatile solids indicated that by manipulation of metabolism of acid producer and methane former microbes through either micronutrients (which served as activators for several enzymes) or adjusting C:N ratio (through protein-rich supplementation) may enhance the scope for enriching methane content in biogas production. This concept was supported by the observations of Satyanarayan et al. (2008) that continuous feeding of a single substrate reduced the production of biogas and its $\%$ methane, while supplementation of additives enhanced both. Towards this objective, the present study has successfully explored the use of pomegranate seed de-oiled cake as a major additive and micronutrients solution as a minor additive to enhance production of biogas and enrich its methane content, using mango peel as the initial substrate.

\section{MATERIALS AND METHODS}

\subsection{Fresh mango peel waste as a substrate}

It was collected at ambient temperature from the fruit processing plant and used within $24 \mathrm{hr}$. Its biochemical characterization is presented in Table 1.

\subsection{Pomegranate seed de-oiled cake as a major additive}

Pomegranate seed de-oiled cake, a byproduct of pomegranate seeds after oil extraction by expeller method, rich in TOC (51.2\%), carbohydrates (46\%), fat (15.8\%), proteins (12\%) and VS (92.5\%) 
(Clesceri et al., 2000) was used as a major additive. Its biochemical analysis is also presented in Table 1.

Table 1. Biochemical characteristics of substrate MP and additive pomegranate seed de-oiled cake

\begin{tabular}{lcc}
\hline \multicolumn{1}{c}{ Parameters $^{a}$} & MP & PSDC \\
\hline Total solids (TS) (\%) & $23.6 \pm 1.3$ & $93.4 \pm 1.6$ \\
Volatile solids (VS) (\%) & $95.2 \pm 0.9$ & $92.5 \pm 0.7$ \\
Total organic carbon (TOC) (\%) & $59.8 \pm 0.6$ & $51.2 \pm 0.9$ \\
Total carbohydrates (\%) & $34.5 \pm 1.1$ & $46.5 \pm 1.3$ \\
Total lignin (\%) & $10.3 \pm 0.5$ & $23.1 \pm 0.6$ \\
Total Kjeldahl nitrogen (TKN) (\%) & $1.3 \pm 0.2$ & $2.3 \pm 0.3$ \\
Total proteins (\%) & $7.6 \pm 0.2$ & $12.6 \pm 0.4$ \\
Total fat (\%) & $\mathrm{NA}$ & $15.8 \pm 0.3$ \\
C:N ratio & $45.4 \pm 0.8$ & $22.3 \pm 0.5$ \\
Total phosphorus (\%) & $0.6 \pm 0.2$ & $0.4 \pm 0.1$ \\
\hline
\end{tabular}

${ }^{a}$ Analysis is an average of 10 estimates reported on dry weight basis;

NA: not analyzed; MP: mango peels; PSDC: pomegranate seed de-oiled cake

Table 2. Chemical composition of micronutrient solution ( $m s)$

\begin{tabular}{lc}
\hline \multicolumn{1}{c}{ Parameters $^{b}$} & $\begin{array}{c}\text { Micronutrients } \\
\text { solution (\%) }\end{array}$ \\
\hline Moisture & 57.36 \\
Chloride (Cl) & 26.20 \\
Iron (Fe) & 13.80 \\
Sodium (Na) & 0.67 \\
Phosphorous (P) & 0.58 \\
Zinc (Zn) & 0.48 \\
Potassium (K) & 0.32 \\
Calcium (Ca) & 0.31 \\
Manganese (Mn) & 0.125 \\
Magnesium (Mg) & 0.083 \\
Cadmium (Cd) & 0.051 \\
Copper (Cu) & 0.007 \\
Lead (Pb) & 0.004 \\
Nickel (Ni) & 0.003 \\
Chromium (Cr) & 0.003 \\
Cobalt (Co) & 0.002 \\
\hline meters were analyzed in GEO-CHEM Lab Pvt. Ltd., Mumbai
\end{tabular}

\subsection{Micronutrient solution as a minor additive}

It is a mixture of minerals containing $13.8 \% \mathrm{Fe}$ (III), $26.2 \%$ chloride, $\mathrm{Na}, \mathrm{K}, \mathrm{Ca}, \mathrm{P}, \mathrm{Zn}, \mathrm{Mn}$ and $\mathrm{Mg}$ in minor quantities as well as $\mathrm{Cd}, \mathrm{Cu}, \mathrm{Pb}, \mathrm{Ni}, \mathrm{Cr}$ and $\mathrm{Co}$ in trace amounts. Its chemical composition is presented in Table 2.

\subsection{Inoculum}

Active slurry $(5 \%, v / v)$ from a $40 \mathrm{~m}^{3} \mathrm{KVIC}$ type mesophilic bioreactor $\left(35^{\circ} \mathrm{C}\right)$ fed with pomegranate seed de-oiled cake and canteen waste plus cattle dung $(47.5 \%$, v/v) and water $(47.5 \%$, v/v) was used as an inoculum ( $10 \%$ of the total substrate suspension volume) in both bioreactors.

\subsection{Experimental set-up}

Anaerobic digestion was carried out in two identical, timer-controlled, semi-continuously stirred (3 min after every $30 \mathrm{~min}$ ) PVC bioreactors, each with a total volume of $25 \mathrm{~L}$, at $35 \pm 1^{\circ} \mathrm{C}$. First bioreactor was fed with the substrate mango peel waste once/day, while second bioreactor used 
mango peels + micronutrient solution. Biogas collection from the bioreactors was made via a flexible heavy duty rubber tube to a separate water displacement transparent fiber glass bottle (20 I capacity) (Figure 1).

The substrate was fed once a day. During the operation of digesters, while digestion was performed using mango peel as the exclusive substrate by gradually increasing the organic loading rate (OLR; $\mathrm{kgVS} / \mathrm{m}^{3} /$ day) from 0.5 to 3.0 over 16 weeks, co-digestion was performed in both the bioreactors from OLR 4.0 onwards by feeding pomegranate seed de-oiled cake as a major additive by gradually increasing the OLR from $4+1.0$ to $4+3.0$, while feeding of mango peel and mango peel + micronutrients solution was kept constant at OLR 4.0.

The micronutrients solution was supplemented arbitrarily at the rate of $1 \mathrm{ml} / \mathrm{OLR}$ on trial basis, assuming that an excess addition could be counter-productive as the margin between its need and deleterious effect(s) being quite thin (Table 2).

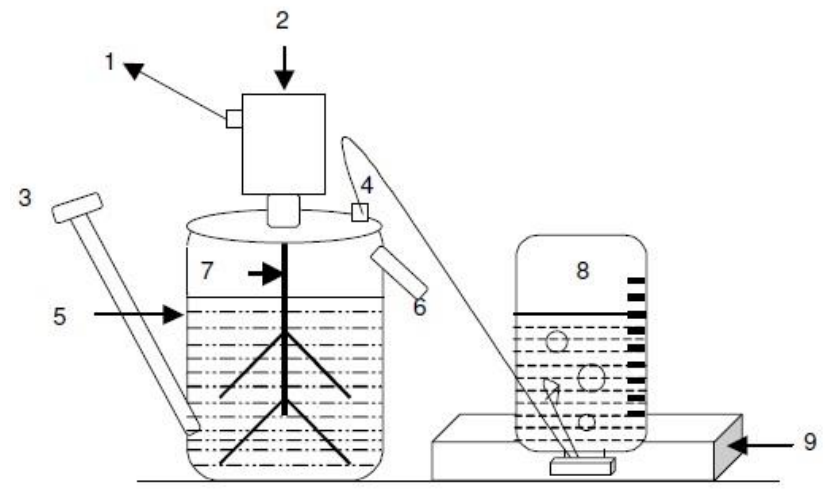

Figure 1. Bioreactor;

1 = Electric panel and timer, $2=$ Agitator motor, $3=$ Bioreactor inlet, $4=$ Biogas exit,

$5=$ Bioreactor, $6=$ Bioreactor outlet, $7=$ Agitator, $8=$ Biogas holder and $9=$ Water bath .

\subsection{Analytical methods}

$\mathrm{TS}, \mathrm{TOC}, \mathrm{VS}, \mathrm{TKN}$ and $\mathrm{pH}$ of the substrate slurry and digestate were analyzed using standard methods as described by Clesceri et al. (2000). Volatile fatty acid (VFA) and methane analysis was done by gas chromatograph (Perkin Elmer, Clarus 500), equipped with flame ionization detector (FID) and thermal conductivity detector (TCD). VFAs were analyzed using FID, capillary column (Elite WAX ETR, $30 \mathrm{~m} \times 0.32 \mathrm{~mm} \times 1.0 \mu \mathrm{m}$ ) and helium as a carrier gas. The detector, injector and oven temperature were $260^{\circ} \mathrm{C}, 240^{\circ} \mathrm{C}$ and $80-230^{\circ} \mathrm{C}$ (programmed), respectively. Methane was analyzed using stainless-steel packed column (HAYSEP-Q, 80/100 mesh, 9' x 1/8' OD). The temperature of detector and injector were $100^{\circ} \mathrm{C}$ and the oven $40^{\circ} \mathrm{C}$.

The measurement of biogas was carried out after every $24 \mathrm{~h}$ using a calibrated transparent fiber glass container of 20 I capacity using water displacement method.

\section{RESULTS AND DISCUSSION}

Using any biodegradable waste for biogas generation has tremendous health, social, technological and financial implications. This is obvious from a fact that in 1947, with 350 million population, India had $33 \%$ forest cover, which has been reduced to merely $11 \%$ in 2007 due to ever increasing population to 1100 million. The reduction in forest cover was primarily due to use of wood for cooking and heating purposes. This trend has reversed by the introduction of about 5 million biogas plants, especially in hilly and rural areas of India, where otherwise deforestation was the only way to procure energy. The trend of converting waste into biogas by anaerobic digestion will increase further awareness of the importance of forest for herbs, forest produce, wild life, entertainment and earning carbon credits from the developed countries required to meet the accepted norms as per Kyoto protocol (Tong and Jaafer, 2006). Biogas generation not only transforms waste into value added green energy, but also improves hygienic conditions for promoting health, besides generates organic manure for sustainable agriculture (Chaudhari and Kothari, 2009).

The biogas plants in India are largely floating dome type (Indian design), fixed dome type (Chinese design), UASB digesters (Dutch design) and Deenbandhu model promoted by the Ministry of Nonconventional Energy Sources (MNES). Most of these biogas plants are constructed using locally 
available raw material to contain cost. The capital cost of a family size digester is about US $\$ 20-$ 30. They are simple in design and operation to cut down the maintenance cost. Its operating cost is almost negligible as locally available cattle dung or night soil is used as substrate. Apparently, the biogas used is $5-7$ fold cheaper as compared to purchasing compressed liquid petroleum gas (LPG) cylinders. Thus, in view of the above facts, India has tangible significant health, social, financial and environmental benefits in promoting anaerobic digestion.

Mango (Mangifera indica) is a major commercial fruit crop in India, it being 55-60 \% of the global producer of range of mango varieties. Being a seasonal crop (during March-June), its preservation/processing was desired to minimize waste by value-addition. Towards this objective, Jain Irrigation Systems Limited (JISL), Jalgaon processes about 60,000 tons mango per annum during which about 30,000 tons of waste (peels, stone, un-ripe and over-ripe fruits) is generated. Biochemical analysis of its peel waste indicated its potential of being resource for biogas production upon microbial fermentation (Gomez et al., 2007).

\subsection{Substrate analysis}

As summarized in Table 1, mango peel has (i) $59.8 \%$ TOC and $95.2 \%$ VS, indicating its rich biogas yielding potential, (ii) $34.5 \%$ carbohydrates, $7.6 \%$ proteins and $0.6 \%$ phosphorus to support microbial growth for expediting anaerobic digestion and (iii) $45.4 \mathrm{C}: \mathrm{N}$ ratio and $10.3 \%$ lignin to slow down its digestion (Yadav et al., 2002). Thus, the rate of biogas production was dependent upon net balance between microbial growth promoters and digestion retarding factors.

\subsection{Effect of pH}

Since $\mathrm{pH}$ of the bioreactor medium has a direct influence on digestion, which in turn is dependent upon microbial growth, which being inhibited by excessive acidity level and variation of $\mathrm{pH}$ in the digesting material affect the AD. The microbes involved in anaerobic digestion have a $\mathrm{pH}$ range of 6.4-7.8, with values close to neutrality for optimal activity (Igoni et al., 2002). As summarized in Table 3, in mango peel, $\mathrm{pH}$ fluctuated in $6.6 \pm 0.8$ range during the increase in OLR from 0.5 to 3.0, which reflected in biogas production in $0.32 \pm 0.02 \mathrm{~m}^{3} \mathrm{~kg}^{-1} \mathrm{VS}$ fed, affecting methane content in $0.23 \pm 0.01 \mathrm{~m}^{3} \mathrm{~kg}^{-1}$ VS fed.

\subsection{Effect of micronutrients solution}

Ferric chloride $\left(\mathrm{FeCl}_{3}\right)$ is a well-known input for the reduction of hydrogen sulfide $\left(\mathrm{H}_{2} \mathrm{~S}\right)$, the toxic gas generated in biogas bioreactor. It reacts with $\mathrm{H}_{2} \mathrm{~S}$ and forms ferrous sulfate, an insoluble entity (Haen and Polman, 2001). This allows uninterrupted continuation of methane production, without causing toxic effect on methanogens. The role of micronutrients solution in higher and lower plants and microbes has been well studied, but the relevance to anaerobic digestion is almost lacking except a few laboratory reports, which have been made mainly on individual strains in chemically defined media (Raju et al., 1991).

Barring an isolated incident, micronutrients solution stabilized the $\mathrm{pH}$ in $7.5 \pm 0.4$ range, reflecting in a relatively stabilized biogas production in higher $\left(0.63 \pm 0.1 \mathrm{~m}^{3} \mathrm{~kg}^{-1} \mathrm{VS}\right.$ fed) range and enriching methane in $0.46 \pm 0.1 \mathrm{~m}^{3} \mathrm{~kg}^{-1} \mathrm{VS}$ fed. As OLR increased, biogas volume $\left(0.60-0.79 \mathrm{~m}^{3} \mathrm{~kg}^{-1} \mathrm{VS}\right.$ fed) and methane (0.40-0.58 $\mathrm{m}^{3} \mathrm{~kg}^{-1} \mathrm{VS}$ fed) also increased (Table 3), which appears to be the result of micronutrients solution addition, to serve as activator for several enzyme systems in the absence of any other change in the operating parameters.

\subsection{Effect of pomegranate seed de-oiled cake on co-digestion}

The use of pomegranate seed de-oiled cake as a substrate for the production of biogas due to its high content of fats and proteins by Suryawanshi et al. (2009) prompted its use as an additive in the anaerobic digestion of mango peels.

It is clear from Table 4 that bioreactors fed exclusively with mango peel and mango peel + micronutrients solution, when supplemented with pomegranate seed de-oiled cake for co-digestion, initially $\mathrm{pH}$ had decreased for 3 weeks, followed by a decrease in biogas production $\left(0.44 \mathrm{~m}^{3} \mathrm{~kg}^{-1} \mathrm{VS}\right.$ fed), but without change in methane content $\left(0.31 \mathrm{~m}^{3} \mathrm{~kg}^{-1} \mathrm{VS}\right.$ fed). Subsequently, the $\mathrm{pH}$ also rose to optimal range, picking up biogas production significantly from 0.50 to $0.52 \mathrm{~m}^{3} \mathrm{~kg}^{-1} \mathrm{VS}$ fed and as high as up to $0.79 \mathrm{~m}^{3} \mathrm{~kg}^{-1} \mathrm{VS}$ fed (with mango peel alone). The same trend was followed by mango peel + micronutrients solution in (i) maintaining $\mathrm{pH}$ in $7.5 \pm 0.4$ range, (ii) biogas production increasing to $0.80 \pm 0.2 \mathrm{~m}^{3} \mathrm{~kg}^{-1} \mathrm{VS}$ fed and (iii) methane content enhancing up to $0.64 \pm 0.2 \mathrm{~m}^{3} \mathrm{~kg}^{-1} \mathrm{VS}$ fed. 
Table 3. Profiles of \% TS, \% VS, OLR, pH, alkali:acid ratio, digested C:N ratio, biogas and methane before addition of PSDC

\begin{tabular}{|c|c|c|c|c|c|c|c|}
\hline Week & $\begin{array}{l}\text { VS fed } \\
\left(\mathbf{k g ~ d a y}^{-1}\right)\end{array}$ & $\begin{array}{c}\text { OLR } \\
\left(\mathrm{kgVS} \mathrm{m}^{-3} \text { day }^{-1}\right)\end{array}$ & pH & $\begin{array}{c}\text { Alk:aci } \\
\text { ratio }\end{array}$ & $\begin{array}{l}\mathrm{C}: \mathrm{N} \\
\text { ratio }\end{array}$ & $\begin{array}{c}\text { Biogas } \\
\text { production } \\
\left(\mathrm{m}^{3} \mathrm{~kg}^{-1} \mathrm{VS} \text { fed }\right)\end{array}$ & $\begin{array}{l}\mathrm{CH}_{4} \text { production } \\
\left(\mathrm{m}^{3} \mathrm{~kg}^{-1} \mathrm{VS} \text { fed }\right)\end{array}$ \\
\hline \multicolumn{8}{|c|}{ MP } \\
\hline \multirow[t]{4}{*}{1} & 0.013 & 0.50 & $7.3 \pm 0.3$ & 3.7 & 13.8 & $0.63 \pm 0.16$ & $0.38 \pm 0.005$ \\
\hline & & & $7.2 \pm 0.2$ & 4.0 & 15.3 & $0.55 \pm 0.08$ & $0.34 \pm 0.003$ \\
\hline & & & $7.1 \pm 0.4$ & 4.4 & 17.2 & $0.63 \pm 0.16$ & $0.41 \pm 0.005$ \\
\hline & & & $7.2 \pm 0.7$ & 4.4 & 16.6 & $0.63 \pm 0.24$ & $0.41 \pm 0.002$ \\
\hline \multirow[t]{4}{*}{5} & 0.025 & 1.00 & $7.1 \pm 0.2$ & 5.3 & 20.2 & $0.47 \pm 0.16$ & $0.31 \pm 0.003$ \\
\hline & & & $6.9 \pm 0.4$ & 5.0 & 18.9 & $0.55 \pm 0.08$ & $0.36 \pm 0.003$ \\
\hline & & & $7.6 \pm 0.7$ & 4.7 & 17.5 & $0.51 \pm 0.08$ & $0.35 \pm 0.002$ \\
\hline & & & $7.6 \pm 0.8$ & 3.5 & 17.2 & $0.55 \pm 0.08$ & $0.38 \pm 0.002$ \\
\hline \multirow[t]{4}{*}{9} & 0.051 & 2.00 & $7.6 \pm 0.1$ & 5.6 & 18.9 & $0.43 \pm 0.04$ & $0.30 \pm 0.002$ \\
\hline & & & $7.7 \pm 0.7$ & 4.8 & 18.9 & $0.58 \pm 0.04$ & $0.38 \pm 0.002$ \\
\hline & & & $7.4 \pm 0.4$ & 4.2 & 18.4 & $0.60 \pm 0.06$ & $0.41 \pm 0.002$ \\
\hline & & & $7.1 \pm 0.1$ & 5.5 & 17.4 & $0.58 \pm 0.08$ & $0.42 \pm 0.005$ \\
\hline \multirow[t]{4}{*}{13} & 0.076 & 3.00 & $7.1 \pm 0.2$ & 7.1 & 17.3 & $0.41 \pm 0.04$ & $0.29 \pm 0.002$ \\
\hline & & & $6.9 \pm 0.4$ & 7.3 & 16.9 & $0.41 \pm 0.01$ & $0.30 \pm 0.000$ \\
\hline & & & $5.8 \pm 0.3$ & 5.7 & 17.9 & $0.27 \pm 0.04$ & $0.19 \pm 0.001$ \\
\hline & & & $6.2 \pm 0.7$ & 3.7 & 19.6 & $0.22 \pm 0.03$ & $0.15 \pm 0.001$ \\
\hline \multicolumn{8}{|c|}{$\mathrm{MP}+m s$} \\
\hline \multirow[t]{4}{*}{1} & 0.013 & 0.50 & $7.3 \pm 0.6$ & 3.7 & 14.8 & $0.71 \pm 0.08$ & $0.47 \pm 0.002$ \\
\hline & & & $7.3 \pm 0.4$ & 4.5 & 14.3 & $0.71 \pm 0.16$ & $0.48 \pm 0.002$ \\
\hline & & & $7.1 \pm 0.2$ & 6.1 & 17.5 & $0.79 \pm 0.08$ & $0.51 \pm 0.003$ \\
\hline & & & $7.2 \pm 0.7$ & 5.0 & 19.2 & $0.87 \pm 0.32$ & $0.57 \pm 0.009$ \\
\hline \multirow[t]{4}{*}{5} & 0.025 & 1.00 & $7.3 \pm 0.6$ & 6.0 & 18.9 & $0.59 \pm 0.16$ & $0.43 \pm 0.006$ \\
\hline & & & $7.1 \pm 0.3$ & 5.7 & 18.6 & $0.67 \pm 0.12$ & $0.48 \pm 0.002$ \\
\hline & & & $7.7 \pm 0.4$ & 7.0 & 18.4 & $0.67 \pm 0.04$ & $0.47 \pm 0.000$ \\
\hline & & & $7.5 \pm 0.8$ & 7.1 & 17.2 & $0.67 \pm 0.12$ & $0.48 \pm 0.006$ \\
\hline \multirow[t]{4}{*}{9} & 0.051 & 2.00 & $7.5 \pm 0.9$ & 6.6 & 17.9 & $0.63 \pm 0.02$ & $0.46 \pm 0.001$ \\
\hline & & & $7.6 \pm 0.1$ & 6.1 & 17.8 & $0.71 \pm 0.08$ & $0.53 \pm 0.002$ \\
\hline & & & $7.5 \pm 0.4$ & 6.3 & 17.5 & $0.79 \pm 0.04$ & $0.58 \pm 0.002$ \\
\hline & & & $7.9 \pm 0.7$ & 6.6 & 17.7 & $0.75 \pm 0.04$ & $0.55 \pm 0.001$ \\
\hline \multirow[t]{4}{*}{13} & 0.076 & 3.00 & $7.7 \pm 0.3$ & 7.8 & 18.2 & $0.63 \pm 0.03$ & $0.47 \pm 0.000$ \\
\hline & & & $7.6 \pm 0.4$ & 7.9 & 18.1 & $0.68 \pm 0.01$ & $0.57 \pm 0.000$ \\
\hline & & & $6.8 \pm 0.5$ & 4.8 & 20.0 & $0.66 \pm 0.03$ & $0.46 \pm 0.001$ \\
\hline & & & $4.9 \pm 0.8$ & 2.4 & 20.6 & $0.60 \pm 0.01$ & $0.40 \pm 0.000$ \\
\hline
\end{tabular}

While all parameters were monitored at $24 \mathrm{~h}$ interval, for the sake of brevity, results are summarized as an average of weeks.

MP: mango peels; PSDC: pomegranate seed de-oiled cake; ms: micronutrient solution 
Table 4. Profile of \% TS, \% VS, VS fed, analysis of digestate, biogas and methane after addition of PSDC

\begin{tabular}{|c|c|c|c|c|c|c|c|}
\hline Week & $\begin{array}{c}\text { VS fed } \\
\left(k^{\prime} \text { day }^{-1}\right)\end{array}$ & $\begin{array}{c}\text { OLR } \\
(\mathrm{MP}+\mathrm{PSDC}) \\
\left(\mathrm{kgVS} \mathrm{m}^{-3} \mathrm{day}^{-1}\right)\end{array}$ & $\mathrm{pH}$ & $\begin{array}{l}\text { Alk:aci } \\
\text { ratio }\end{array}$ & $\begin{array}{l}\mathrm{C}: \mathrm{N} \\
\text { ratio }\end{array}$ & $\begin{array}{c}\text { Biogas } \\
\text { production } \\
\left(\mathrm{m}^{3} \mathrm{~kg}^{-1} \mathrm{VS} \text { fed }\right)\end{array}$ & $\begin{array}{l}\mathrm{CH}_{4} \text { production } \\
\left(\mathrm{m}^{3} \mathrm{~kg}^{-1} \mathrm{VS} \text { fed }\right)\end{array}$ \\
\hline \multicolumn{8}{|c|}{ MP+PSDC } \\
\hline \multirow[t]{4}{*}{17} & 0.126 & $4+1$ & $4.7 \pm 0.6$ & 2.3 & 20.2 & $0.44 \pm 0.02$ & $0.31 \pm 0.001$ \\
\hline & & & $5.4 \pm 0.4$ & 1.6 & 22.5 & $0.50 \pm 0.02$ & $0.36 \pm 0.000$ \\
\hline & & & $6.7 \pm 0.4$ & 1.6 & 21.2 & $0.52 \pm 0.01$ & $0.37 \pm 0.000$ \\
\hline & & & $7.4 \pm 0.2$ & 6.4 & 17.3 & $0.57 \pm 0.02$ & $0.42 \pm 0.001$ \\
\hline \multirow[t]{4}{*}{21} & 0.152 & $4+2$ & $7.6 \pm 0.5$ & 8.4 & 15.0 & $0.61 \pm 0.0 .4$ & $0.44 \pm 0.002$ \\
\hline & & & $7.7 \pm 0.4$ & 5.1 & 15.4 & $0.66 \pm 0.02$ & $0.46 \pm 0.000$ \\
\hline & & & $7.6 \pm 0.4$ & 6.8 & 15.0 & $0.74 \pm 0.01$ & $0.52 \pm 0.000$ \\
\hline & & & $7.8 \pm 0.7$ & 6.1 & 15.9 & $0.77 \pm 0.02$ & $0.53 \pm 0.000$ \\
\hline 25 & 0.177 & $4+3$ & $7.6 \pm 0.2$ & 6.7 & 18.5 & $0.79 \pm 0.04$ & $0.55 \pm 0.002$ \\
\hline \multicolumn{8}{|c|}{$\mathrm{MP}+m s+\mathrm{PSDC}$} \\
\hline \multirow[t]{4}{*}{17} & 0.126 & $4+1$ & $5.1 \pm 0.4$ & 2.0 & 20.5 & $0.71 \pm 0.02$ & $0.52 \pm 0.000$ \\
\hline & & & $5.5 \pm 0.2$ & 1.6 & 26.9 & $0.70 \pm 0.04$ & $0.52 \pm 0.001$ \\
\hline & & & $7.0 \pm 0.3$ & 2.8 & 25.4 & $0.72 \pm 0.02$ & $0.56 \pm 0.001$ \\
\hline & & & $7.6 \pm 0.4$ & 3.9 & 17.4 & $0.75 \pm 0.03$ & $0.61 \pm 0.001$ \\
\hline \multirow[t]{4}{*}{21} & 0.152 & $4+2$ & $7.7 \pm 0.8$ & 5.7 & 17.7 & $0.76 \pm 0.01$ & $0.64 \pm 0.000$ \\
\hline & & & $7.8 \pm 0.4$ & 6.3 & 18.7 & $0.79 \pm 0.04$ & $0.61 \pm 0.001$ \\
\hline & & & $7.8 \pm 0.5$ & 5.8 & 18.0 & $0.82 \pm 0.03$ & $0.63 \pm 0.001$ \\
\hline & & & $7.7 \pm 0.4$ & 6.6 & 18.5 & $0.80 \pm 0.01$ & $0.61 \pm 0.000$ \\
\hline 25 & 0.177 & $4+3$ & $7.5 \pm 0.2$ & 7.0 & 18.0 & $0.81 \pm 0.02$ & $0.61 \pm 0.001$ \\
\hline
\end{tabular}

${ }^{d}$ Results are weekly averages as in Table 3. ; MP: mango peels; PSDC: pomegranate seed de-oiled cake; $m s$ : micronutrient solution

\subsection{Alkalinity: acidity ratio}

From Table 3, it is clear that the trend of $\mathrm{pH}$ fluctuation/maintenance in both bioreactors was followed by alkalinity:acidity ratio. Basically, alkalinity:acidity ratio provided buffering capacity to $\mathrm{pH}$ stability. Therefore, it could also depend upon substrate(s) and in turn, upon their chemical composition. Barring initial fluctuations, in mango peel, the ratio changed in 4.4-7.3 range, in mango peel + micronutrients solution, it was 5.0-7.9 and with the addition of pomegranate seed de-oiled cake, it increased as a function of OLR from 6.4-6.7 in mango peel and 5.7-7.0 in mango peel + micronutrients solution (Table 4). It may be concluded that the role of pomegranate seed de-oiled cake was buffering the medium, stabilizing the $\mathrm{pH}$ and thereby stabilizing methane production at higher level as seen from Table 4.

\subsection{Effect of VFA production}

It has been observed that a process imbalance results when the rate of VFA formation exceeds the rate of methane formation, concurrently $\mathrm{pH}$ decreases, biogas production reduces and its $\mathrm{CO}_{2}$ content also increases (Eckenfelder, 2000). According to Igoni et al. (2008), pH exerted an over all effect on the whole process of biogas production. To ward off this contingency of VFA accumulation, sufficient alkalinity has to be available all times for sufficient buffering, to ensure more biogas formation, also its high methane content.

Since $\mathrm{pH}$ reduction gives an idea of imbalance already occurred in the process, basically it is similar to post-mortem process. Better alternative is to monitor the concentration of individual VFAs, since they indicate metabolic status of some of the most delicate microbial groups in the anaerobic system and their profile gives a pre-emptive handle to change the course of reactions in anaerobic digestion 
from impending problem to process normalization (Ahring et al., 1995). For example, an accumulation of propionic acid may indicate the digestion chain being overloaded (Fukuzaki et al., 1990; Kus and Wiesmann, 1995). Feeding stoppage for some period could arrest acceleration of propionic acid accumulation and put the process on right track, which otherwise after having gone off the track, takes quite long period to resume normal path.

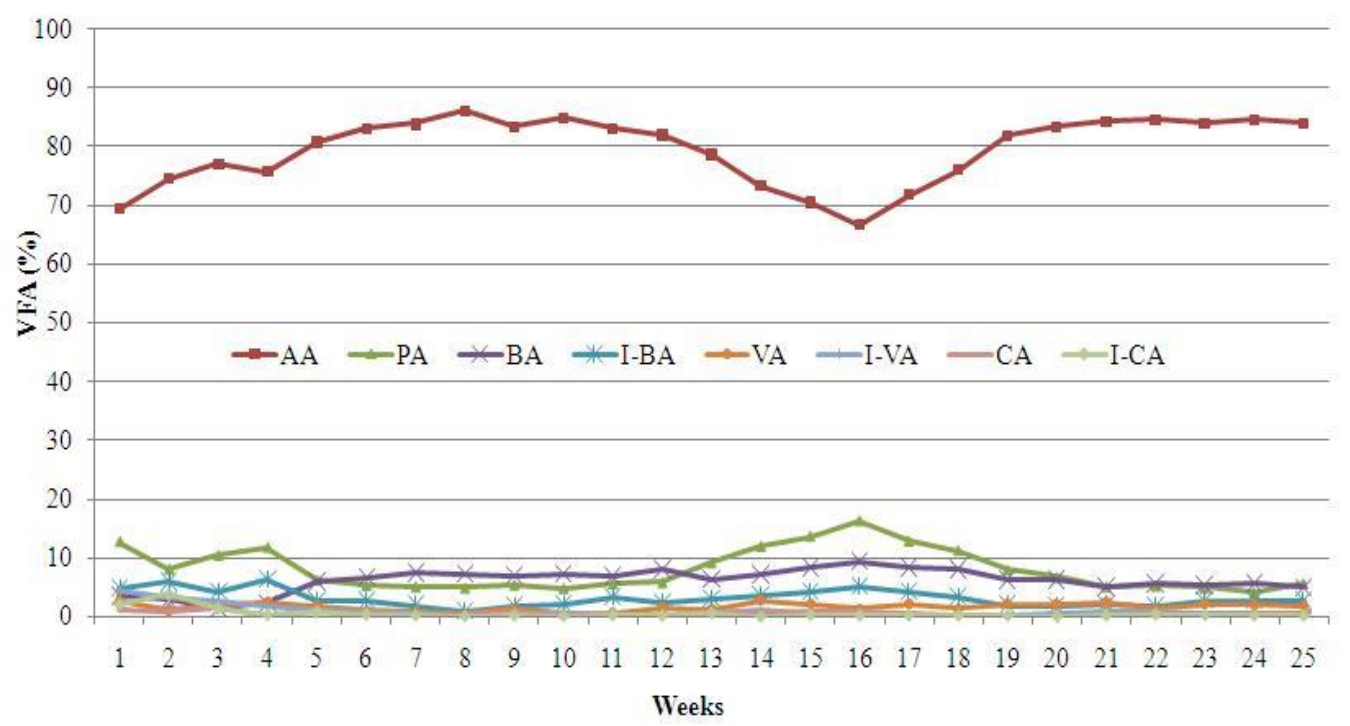

Figure 2. Profile of VFAs in MP amd MP+PSDC

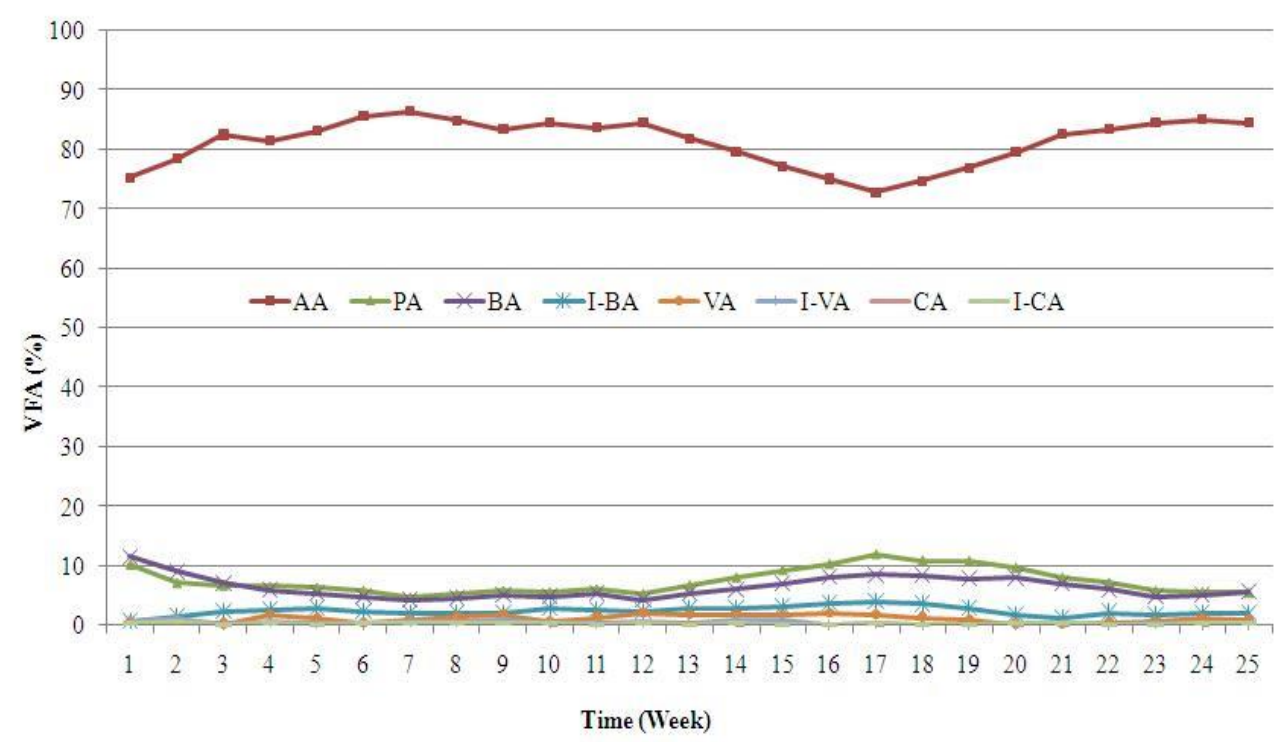

Figure 3. Profile of VFAs in MP+ms and MP+ms+PSDC

Figure 2 has indicated that concentration of VFAs in mango peel have increased as a function of increase in OLR, resulting in the increased production of biogas $\left(0.22-0.63 \mathrm{~m}^{3} \mathrm{~kg}^{-1} \mathrm{VS}\right.$ fed) and methane (0.15-0.42 $\mathrm{m}^{3} \mathrm{~kg}^{-1} \mathrm{VS}$ fed). This trend was consistent with the stability of $\mathrm{pH}$. At OLR 3.0 , concentration of acetic acid (AA, 66-70 \%) decreased, while that of propionic acid (PA, 10-13\%), butyric acid (BA, 7-9 \%), iso-butyric acid (I-BA, 3-5\%), valeric acid (VA, 1-2 \%), iso-valeric acid (IVA, 0.6-1.0 \%), caproic acid (CA, 0.6-0.9\%) and iso-caproic acid (I-CA, 0.3-0.6\%) increased, presumably due to overloading of the substrate. With the addition of pomegranate seed de-oiled cake, \% AA increased and at the same time, PA (4-6\%), BA (4-6\%), I-BA (1-2\%), VA (1-2\%), I-VA (0.4-0.9\%), CA (0-0.6\%) and I-CA (0.2-0.4\%) decreased, while methane \% re-stabilized in 80-84 $\%$ range. Increased PA (16.2 \%) was responsible for reducing the $\mathrm{pH}$ for 3 weeks; had pomegranate seed de-oiled cake not buffered the medium, digester failure was eminent as pointed out by many researchers (Nanba at al., 1983; Fukuzaki et al., 1990). 
From Fig. 3, it is clear that the trend followed in mango peel by AA (75-85\%) was repeated in mango peel + micronutrients solution also, with other VFAs in normal range. The biogas production and its methane content also showed the same trend as a function of increase in OLR, minimal fluctuation in $\mathrm{pH}$ and alkalinity:acidity ratio.

From these observations, it is clear that, if the $\mathrm{pH}$ of the bioreactor is relatively stable around 7.0, production of $A A$ is in high range, which in turn increases biogas production as well as its methane content.

\subsection{Effect of co-digestion of mango peel and mango peel + micronutrients solution with pomegranate seed de-oiled cake}

It is clear from Table 4, that the quantity of pomegranate seed de-oiled cake increased the OLR, with increase in biogas production. Barring the transient effect of fall in $\mathrm{pH}$, alkalinity:acidity and $\mathrm{C}: \mathrm{N}$ ratio after addition of pomegranate seed de-oiled cake to mango peel and mango peel + micronutrient solution, it was stabilized in the optimal range giving higher production of biogas and \% methane. The comparative account of co-digestion of mango peel and mango peel + micronutrients solution is summarized in Table 5. In conclusion, pomegranate seed de-oiled cake appeared to be a supportive additive to recover both the digesters from trouble leading to failure and increase in biogas as well as methane content.

Table 5. Physico-chemical characteristics of experimental digesters as a function of feeding

\begin{tabular}{|c|c|c|c|c|}
\hline Parameters & MP & $\mathrm{MP}+m s$ & $\begin{array}{l}\text { MP + } \\
\text { PSDC }\end{array}$ & $\begin{array}{c}\text { MP+ms+ } \\
\text { PSDC }\end{array}$ \\
\hline & \multicolumn{2}{|c|}{ Before co-digestion } & \multicolumn{2}{|c|}{ After co-digestion } \\
\hline OLR (kgVS m-3 day $\left.{ }^{-1}\right)$ & \multicolumn{2}{|c|}{$0.50-3.00$} & $4.0-7.0$ & $4.0-7.0$ \\
\hline $\mathrm{pH}$ & 7.1 & 7.2 & 6.9 & 7.0 \\
\hline Alkali:acidity ratio & 4.9 & 5.8 & 5.0 & 4.6 \\
\hline $\mathrm{C}: \mathrm{N}$ ratio & 17.6 & 17.9 & 17.9 & 20.1 \\
\hline Total solids (\%) & 3.0 & 3.4 & 4.2 & 5.3 \\
\hline Total VS fed (\%) & 95.3 & 95.3 & 95.6 & 95.7 \\
\hline Total VS out (\%) & 71.9 & 68.4 & 69.8 & 65.4 \\
\hline Total VS reduction (\%) & 23.4 & 26.9 & 25.8 & 30.3 \\
\hline Biogas production ( $\mathrm{m}^{3} \mathrm{~kg}^{-1} \mathrm{VS}$ fed) & 0.63 & 0.87 & 0.79 & 0.82 \\
\hline Methane content ( $\mathrm{m}^{3} \mathrm{~kg}^{-1} \mathrm{VS}$ fed) & 0.42 & 0.58 & 0.55 & 0.64 \\
\hline
\end{tabular}

\subsection{Effect of OLR}

The production of VFAs squarely depends upon the OLR. In case of OLR overloading, pH reduction occurs. This is due to yet unaffected rate of VFA production, but affected rate of VFA consumption or methane formation. This happens due to relatively less sensitivity of acid formers to $\mathrm{pH}$ fluctuations compared to more sensitivity of methane formers. Thus, microbial population involved in the anaerobic digestion process get inhibited, which results into higher concentration of VFAs, specifically PA and others, which is responsible for the souring of digester, which if remained unattended for long results into failure.

It is clear from Table 3 and 4 that, biogas production and methane content increased as OLR increased in both bioreactors. Kirtane et al. (2009) used mango peel as a sole substrate to optimize OLR and suggested that OLR 3.5 was the most suited OLR to produce maximum biogas. In this study, up to OLR 3.0, only single substrate mango peel or mango peel + micronutrients solution was used. The transient fall in $\mathrm{pH}$ to 5.8 in MP and 4.9 in mango peel + micronutrients solution resulted in slight drop in biogas production in MP $\left(0.22 \mathrm{~m}^{3} / \mathrm{kg} \mathrm{VS} \mathrm{fed)}\right.$ without change in methane content $\left(0.15 \mathrm{~m}^{3} \mathrm{~kg}^{-1} \mathrm{VS}\right.$ fed $)$. In case of mango peel + micronutrients solution, there was no change in 
biogas production $\left(0.60 \mathrm{~m}^{3} \mathrm{~kg}^{-1} \mathrm{VS}\right.$ fed), but fluctuation in methane content $\left(0.40 \mathrm{~m}^{3} \mathrm{~kg}^{-1} \mathrm{VS}\right.$ fed). It again proved that high OLR resulted in fall in pH as suggested by Kirtane et al. (2009).

To recover from this trouble, the chance of co-digestion was taken. After addition of pomegranate seed de-oiled cake, the trend changed drastically in the form of stability in $\mathrm{pH}$, alkalinity:acidity and lowering of $\mathrm{C}: \mathrm{N}$ ratio, with an increase in biogas production and methane content. During codigestion, the OLR of the mango peel and mango peel + micronutrients solution were increased with pomegranate seed de-oiled cake from $4+1$ to $4+3$. pomegranate seed de-oiled cake acted as a supplementary additive to the MP and MP+ micronutrients solution and resulted into maximum biogas production $\left(0.79,0.81 \mathrm{~m}^{3} \mathrm{~kg}^{-1} \mathrm{VS}\right.$ fed) and methane content $\left(0.55,0.61 \mathrm{~m}^{3} \mathrm{~kg}^{-1} \mathrm{VS}\right.$ fed) with increased in OLR i.e. up to 7.0. Suryawanshi et al. (2009) used pomegranate seed de-oiled cake as a sole substrate for anaerobic digestion and reported maximum of $36 \mathrm{~L} /$ day biogas production and $74 \%$ methane with OLR 3.50. Here, MP and MP+ micronutrients solution fed with constant OLR 4.0 and pomegranate seed de-oiled cake fed with OLR 3.0 which cumulatively formed OLR 7.0.

\subsection{C: $\mathrm{N}$ ratio}

Ratio of carbon to nitrogen ( $\mathrm{C}: \mathrm{N}$ ratio) determines the performance of anaerobic digestion. Whereas, carbon constitutes the source energy for the microbes present in anaerobic digestion, nitrogen serves to enhance their growth and excess could be free ammonia resulting into toxicity. It has been found that these microbes use up carbon present 30-35 times faster than the rate at which they consume nitrogen. Therefore, for the optimal process, C:N ratio should be about 30:1 in the raw material (Igoni et al., 2008). Taking this into account, C:N ratio of MP 45.5 fed to the bioreactors was reduced by pomegranate seed de-oiled cake for facilitated anaerobic digestion (Table 1). This high $\mathrm{C}: \mathrm{N}$ ratio after digestion decreased to $13-20$ in mango peel and 14-20 in mango peel + micronutrients solution, to be used as a soil conditioner (Chaudhari and Kothari, 2009).

\section{CONCLUSION}

Anaerobic digestion studies on mango peel, mango peel + micronutrients solution and MP+ micronutrients solution + pomegranate seed de-oiled cake indicated that it is possible to enhance biogas production and enrichment of methane in mango peel with feed stock amendment with either micronutrients solution or pomegranate seed de-oiled cake or both. While micronutrients solution may have activated enzymes for optimal production of biogas/methane, ferric chloride may catalyzed smooth anaerobic digestion, presumably minimizing the effect of $\mathrm{H}_{2} \mathrm{~S}$ toxicity. Similarly, pomegranate seed de-oiled cake seems to have provided buffering capacity, stabilized the $\mathrm{pH}$, optimum alkalinity:acidity ratio and reduced $\mathrm{C}: \mathrm{N}$ ratio for facilitated digestion. Cumulative effect was enhanced biogas generation and its rich methane content.

\section{Acknowledgement}

The authors are grateful to Mr. B. H. Jain, Founder Chairman, JISL for providing state-of-the-art R \& $D$ facilities to undertake the present work.

List of acronyms used in the text

\begin{tabular}{|l|l|l|l|}
\hline AA & Acetic acid & KVIC & $\begin{array}{l}\text { Khadi and Village Industrial } \\
\text { Commission }\end{array}$ \\
\hline AD & Anaerobic digestion & MP & Mango peels \\
\hline BA & Butyric acid & OLR & Organic Loading Rate \\
\hline C:N ratio & Carbon nitrogen ratio & PA & Propionic acid \\
\hline CA & caproic acid & PVC & Polyvinyl Chloride \\
\hline I-BA & iso-butyric acid & TKN & Total Kjeldahl Nitrogen \\
\hline I-CA & iso-caproic acid & TOC & Total Organic Carbon \\
\hline I-VA & iso-valeric acid & TS & Total Solids \\
\hline JISL & Jain Irrigation Systems Limited & VA & Valeric acid \\
\hline VFA & Volatile fatty acids & VS & volatile solids \\
\hline
\end{tabular}




\section{REFERENCES}

1. Ahring B., Sandberg M. and Angelidaki I., (1995), Volatile fatty acids as indicator of process imbalance in anaerobic digesters, Appl. Microbiol. Biotechnol., 43, 559-565.

2. Chaudhari A.B. and Kothari R.M., (2009), Soil conditioners as a pivotal biotech input for integrated farming and contingency income, In: A Text Book of Molecular Biotechnology, Chauhan A.K., Varma A. (Eds), Chapter 11, I. K. International Publishing House Pvt. Ltd., New Delhi, pp. 483-505.

3. Clesceri L.S., Greeberg A.E. and Eaton A.D., (2000), Standard methods for the examination of water and wastewater. American Public Health Association (APHA), $20^{\text {th }}$ edn. Washington, D C, USA.

4. Eckenfelder Jr W.W., (2000), Industrial water pollution control. Boston Burr Ridge. McGraw Hill Higher Education.

5. Fukuzaki S., Nishio N., Shobayashi M. and Nagai S., (1990), Inhibition of the fermentation of propionate to methane by hydrogen, acetate and propionate, Appl. Environ. Microbiol., 56, 719723.

6. Gomez L.C., Fernandez G.B., Garcia H.F., Rodriguez M.J.M. and Vereda A.C., (2007), Biomethanization of mixtures of fruits and vegetables solid wastes and sludge from a municipal wastewater treatment plant, J. Environ. Sci. Hith. Part A- Toxic/Hazardous Substances Environ. Engg., 42, 481-487.

7. Hagen M. and Polman E., (2001), Adding gas from biomass to the gas grid. Final report submitted to Danish Gas Agency.

8. Igoni A.H., Ayotamuno M.J., Eze C.L., Ogaji S.O.T. and Probert S.D., (2008), Design of anaerobic digester for producing biogas from municipal solid waste, Appl. Energy, 85, 430-438.

9. Kirtane R.D., Suryawanshi P.C., Patil M.R., Chaudhari A.B. and Kothari R.M., (2009), Optimization of organic loading rate for different fruit wastes during biomethanization, J. Sci. Ind. Res., 68, 252255.

10. Kus F. and Wiesmann U., (1995), Degradation kinetics of acetate and propionate by immobilized anaerobic mixed culture, Water Res., 29, 1437-1443.

11. Nanba A., Nukada R. and Nagai S., (1983), Inhibition by acetic and propionic acids of the growth of Propionibacterium shermanii, J. Ferment. Technol., 61, 551-556.

12. Raju N.R., Sumithra Devi S. and Nand K., (1991), Influence of trace elements on biogas production from mango processing waste in $1.5 \mathrm{~m}^{3} \mathrm{KVIC}$ digesters, Biotechnol. Lett., 13, 461-464.

13. Satyanarayan S., Murkute P. and Ramakant (2008), Biogas production enhancement by Brassica compestries amendment in cattle dung digesters, Biomass Bioenergy, 32, 210-215.

14. Suryawanshi P.C., Kirtane R.D., Chaudhari A.B. and Kothari R.M., (2009), Conservation and recycling of pomegranate seeds and shells for value addition, J. Renew. Sustainable Energy, 1, 013107.

15. Tong S.I. and Jaafer A.B., (2006), POME biogas capture, upgrading and utilization, Palm Oil Engg. Bull., 78, 11-17.

16. Yadav K.R., Sharma R.K. and Kothari R.M., (2002), Eco-friendly bioconversion of eucalyptus bark waste into soil conditioner, Biores. Technol., 81, 163-165. 